\title{
Discursive realization of threat in pre-election communication
}

\author{
Aleksey Romanov ${ }^{1,2}$ and Olga Novoselova ${ }^{1}$ \\ ${ }^{1}$ Tver State Agricultural Academy \\ Tver, Russia \\ ${ }^{2}$ Tver State University \\ Tver, Russia
}

\begin{abstract}
This article focuses on the question of pragmatic effectiveness of threat statements in political communication, in particular, the relevance of using threats in pre-election programs and intimidating voters with the goal of forcing them to vote for a certain politician. The aim of this article is to consider pre-election threat statements as verbal regulative actions and to propose a typology of such constructive menacives taking into account the targeted orientation of their consequent component. This study is based on a corpus of threat statements realized in the presidential candidates' pre-election programs in Russia in 2018. The total number of menacives is 229. The study investigated the data from the perspective of the theory of speech activity, speech act theory and psychosemantics. The theoretical framework of the study is an action-related approach to the analysis of speech (dialogic) acts developed in Tver semantic and pragmatic research school (Romanov 1988; 2002; 2020). The study specified 18 targeted types of menacives that have a certain pragmatic and emotional effect on voters and are characterized by different frequencies in pre-election programs. This result demonstrates that the author of the pre-election program does not know mass voter's preferences, their emotional state and feelings well; therefore, the politician directs their menacing influence on a wide range of potential voters. The authors conclude that politicians deliberately prefer to use threat statements with negative effect on an unfocused audience trying to win the attention and votes. The analysis shows that four types of threat statements with different targeting of consequent component proved to be a pragmatically effective tool in the Russian pre-election campaign in 2018. The results of this study can be used to predict the pragmatic effect of politicians' threat statements on voters.
\end{abstract}

Keywords: political communication, pre-election discourse, statements with the meaning of threat, pragmatics, addressee, Russian language

\section{For citation:}

Romanov, Aleksey and Olga Novoselova. 2020. Discursive realization of threat in pre-election communication. Russian Journal of Linguistics 24 (2). 419 - 448. DOI: 10.22363/2687-00882020-24-2-419-448 
Научная статья

\title{
Дискурсивная реализация угрозы в предвыборной коммуникации
}

\author{
А.А. Романов ${ }^{1,2}$, О.В. Новоселова ${ }^{1}$ \\ ${ }^{1}$ Тверская государственная сельскохозяйственная академия \\ Тверь, Россия \\ 2 Тверской государственный университет \\ Тверь, Россия
}

\begin{abstract}
Аннотация
В статье поднимается вопрос прагматической эффективности реализации высказыванийугроз (менасивных высказываний или менасивов) в политической коммуникации, а именно целесообразности использовать угрозы в предвыборных программах и угрожать избирателям с целью побудить их проголосовать за конкретного политика. Цель статьи — рассмотрев предвыборные высказывания со значением угрозы как вербальные регулятивные действия, предложить типологию таких конструктивных менасивов с учетом адресатной направленности их консеквентного компонента. Материалом исследования послужили менасивные высказывания, реализованные в предвыборных программах кандидатов на пост Президента Российской Федерации в 2018 году. Общее число менасивов составляет 229 единиц. В ходе исследования применялся инструментарий теории речевой деятельности, теории речевых актов и психосемантики. Теоретическим основанием исследования принимается деятельностный подход к анализу речевых (диалогических) единств, разработанный в Тверской семантико-прагматической научной школе (Романов 1988; 2002; 2020). В ходе исследования выделено 18 адресатных разновидностей менасивов, которые обладают определенным прагмаэмоциональным воздействием на избирателей и характеризуются различной частотностью употребления в предвыборных программах. Полученный результат свидетельствует о том, что автор предвыборной программы недостаточно хорошо знает предпочтения массового избирателя, его эмоционального состояния и переживаний, поэтому политик ориентирует свое менасивное воздействие на широкий круг потенциальных избирателей. Авторы приходят к выводу, что политики целенаправленно предпочитают использовать высказывания-угрозы с консеквентными последствиями для нефокусной аудитории, пытаясь таким образом завоевать внимание и голоса избирателей. Проведенный анализ показывает, что использование политиком четырех разновидностей высказываний-угроз с различной адресатной направленностью консеквентного компонента является прагматически эффективным инструментом воздействия в контексте российского предвыборного дискурса 2018 года. Результаты исследования могут быть использованы для прогнозирования прагматического воздействия менасивных высказываний политиков на избирателей.
\end{abstract}

Ключевые слова: политическая коммуникачия, предвыборный дискурс, высказывания со значением угрозы, прагматика, адресат, русский язык

\section{Для цитирования:}

Романов А.А., Новоселова О.В. Дискурсивная реализация угрозы в предвыборной коммуникации // Russian Journal of Linguistics. 2020. Т. 24. № 2. С. 419-448. DOI: 10.22363/2687-0088-2020-24-2-419-448 


\section{1. Введение}

Политический дискурс представляет собой особый тип коммуникативносоциального взаимодействия, который опирается на определенный набор вербальных и невербальных средств, свойственных тому или иному политическому субъекту - лидеру государства, политику, партии - и направлен на «завоевание, удержание и использование государственной власти» (Романов 2002: 3 -5; см. также Кастельс 2016; Най 2006; Vosoughi, Roy \& Aral 2018). Политический предвыборный дискурс отражает текущую речевую деятельность политика, реализуемую в агональном (состязательном) коммуникативном пространстве и сформированную возникающими в результате этой деятельности произведениями - высказываниями, текстами и коммуникатами как поликодовыми образованиями, которые выполняют агитационно-воздействующую функцию (Романов, Романова, Воеводкин 2000: 17; Khanna 2016; Schlenker \& Weigold 1990). В этом смысле предвыборный дискурс выступает в виде определенных, построенных по типовому образцу (схеме, фрейму) речевых (дискурсивных) практик, действий или коммуникативных актов кандидата на тот или иной политический пост (Романов 2002: 25; подробнее о фрейме см.: Романов 1988; 2020), которые маркируются различными лингвориторическими средствами языка и ориентированы на процесс завоевания или удержания политиком власти, а также на привлечение внимания массовой аудитории к его программе, имиджу, личности (Mattern 2005; Schlenker 2003).

Неотъемлемой составляющей агитационно-воздействующей деятельности претендента на тот или иной политический пост является его предвыборная программа, при помощи которой он активно продвигает свою позицию по ключевым вопросам устройства страны и оказывает прагма-эмоциональное воздействие на избирателей. Программные материалы являются результатом тщательной работы политика и его команды и функционируют на фоне особого контекста предвыборного дискурса, который характеризуется отсутствием непосредственной связи политика как отправителя и избирателя как получателя сообщения (Новоселова 2019). В таком контексте политик реализует свое коммуникативное проявление осознанно и в рамках лимологических параметров толерантности, справедливости и элементарной вежливости (подробнее о лимологических границах коммуникативных категорий толерантности и справедливости см.: Новоселова 2017; 2017a). Отличительной прагматической особенностью предвыборных программ является то, что их автор не может корректировать оказываемое им вербальное воздействие на аудиторию, так как он не имеет возможности получить мгновенную ответную реакцию адресата своих посланий и направить ход интерактивного взаимодействия в нужное ему русло согласованного или деструктивного взаимодействия (подробнее см.: Романов 1988). Иначе говоря, в отличие от устных выступлений политиков или дебатов с их участием, в ходе которых можно 
варьировать интенсивную «глубину» воздействия на собеседников, оппонентов и фокусную аудиторию (Новоселова 2019), предвыборные программы представляют собой письменно зафиксированные документы, распространяемые в печатном или электронном виде.

Примечательно, что политики отражают в своих программных материалах не только предлагаемые им пути развития страны, но и используют те языковые средства, с помощью которых планируют оказать определенное прагма-эмоциональное воздействие на электорат. Поэтому со всей уверенностью можно утверждать, что предвыборная программа представляет собой дискурсивное проявление кандидата (или его предвыборный дискурс), состоящее из совокупности языковых практик различной интенциональной направленности и ориентированное в агональном (состязательном) политическом пространстве на побуждение избирателей проголосовать за автора такой программы. Не вызывает сомнений, что для воздействия на массовое сознание избирателей авторы предвыборных программ активно используют политические лозунги, обещания и различного рода гарантии, принцип работы которых понятен и логичен: политик обещает, а избиратель, если верит в обещание, то голосует за такого политика, а если не верит, то предпочитает иного кандидата. Вполне очевидно, что в таких высказываниях-обещаниях кандидат строит образ будущего, в котором будут решены актуальные проблемы страны и созданы благополучные условия для жизни граждан, например: (1) Я предлагаю пойти навстречу такому будущему и сделать Россию прогрессивным и процветающим государством, которое уважает своих граждан и заботится об их развитии, благосостоянии и безопасности (Явлинский).

Особое место в программных материалах политиков занимают высказывания со значением угрозы, механизм воздействия которых на массовое сознание избирателей до конца не изучен (ср. однако: Лайнбарджер 2013; Романов, Новоселова 2013; 2013a; Black 1993; Leonard 2016), но которые активно и осознанно используются претендентами на самый высокий политический пост в стране. Высказывания со значением угрозы (также высказыванияугрозы, менасивные высказывания или менасивы) представляют собой естественно-языковые практики, которые направлены на побуждение единичного, группового или массового адресата к совершению каузируемых действий или отказу от них под действием возможных последствий / санкций, способных порождать в ментальном пространстве адресата аффицированное (т.е. затронутое, задетое аффектом, от лат. afficio «причинять») или дискомфортное эмоциональное состояние (Романов, Новоселова 2013: 5; подробнее о роли эмоционально-прагматического компонента в структуре воздействующего механизма массмедийного послания см.: Романов, Ульянич 2014: 97-112). Данный тип высказываний характеризуются антецедентно-консеквентной связью между каузируемым говорящим действием и негативными последствиями за отказ от его выполнения (Романов, Новоселова 2013: 5; 
2020). Важно отметить, что совершение менасивных действий автором угрозы не является его коммуникативной интенцией, так как, используя высказывание-угрозу как акт побуждения (каузации) под действием наказания, он желает воздействовать упоминанием возможного наказания на эмоциональное состояние собеседника с целью побудить данного собеседника совершить определенные действия (подробнее о каузативном значении угрозы см.: Вежбицка 1985: 267-268; Rehbein 1977).

Следует уточнить, что в предвыборных высказываниях-угрозах политики не строят образ «светлого» будущего для избирателей, а, наоборот, возвращают их к реальности: к экономическим, социальным и политическим проблемам, а также к осознанию необходимости бороться за улучшение ситуации в стране и выбрать того кандидата, который сможет преодолеть вызовы современности, например: (2) Пора вести обстоятельный диалог и находить точки соприкосновения, чтобы снять санкции и отменить антисанкции, которые наносят большой вред экономике и уровню жизни людей в России (Явлинский); (3) Российские неолибералы продолжают вести страну по пути дальнейшей «коммерцуиализации жизни» во всех сферах, в том числе, таких жизненно важных для людей, как медицина, образование, снабжение продовольствием, жилищно-коммунальное обеспечение, они толкают Россию к дальнейшей нравственной, физической, технологической деградации (Бабурин). Получается, что политики реализуют высказывания со значением угрозы в программных материалах целенаправленно, решая коммуникативную задачу воздействия на массовое сознание избирателей возможными негативными последствиями, санкциями для того, чтобы побудить их проголосовать за свою кандидатуру.

\section{2. Методика и задачи исследования}

Отмеченные обстоятельства обусловливают необходимость рассмотрения предвыборных высказываний-угроз как особого дискурсивного проявления политика с целью привлечения внимания избирателей к своей кандидатуре. Вполне закономерно возникает вопрос прагматической эффективности реализации угрозы в дискурсивном пространстве политической коммуникации, а именно уместности и целесообразности для кандидатов использовать менасивные высказывания в программных материалах, тем более угрожать избирателям, с целью побудить их проголосовать за свою кандидатуру. Цель статьи - рассмотрев предвыборные высказывания со значением угрозы как вербальные регулятивные действия, предложить типологию таких конструктивных менасивов с учетом адресатной направленности их консеквентного компонента. С указанных позиций перспективно выяснить, как политику удается показать преимущества предлагаемой им программы развития государства, используя высказывания со значением угрозы, и в адрес каких категорий граждан, социальных слоев и групп населения направлено воздействие предвыборных менасивов претендентов на самый высокий политический пост 
в стране в 2018 году. Целесообразно обратить особое внимание на необходимое и достаточное количество высказываний-угроз для их эффективного функционирования в программных материалах в качестве средства политической борьбы за голоса избирателей.

Изучение и описание прагма-эмоционального воздействия предвыборных менасивов требует синтеза когнитивного и коммуникативного подходов, что обусловливает применение инструментария теории речевой деятельности, теории речевых актов и психосемантики. Теоретическим основанием исследования прагматической специфики предвыборных высказываний-угроз принимается деятельностный подход к анализу речевых (диалогических) единств, разработанный в Тверской семантико-прагматической научной школе, в основе которого лежит регулятивная модель диалогического общения, теория регулятивной деятельности и ее единиц - регулятивов, предложенная профессором А.А. Романовым (1988; 2020). Выбранный функционально-семантический подход к описанию менасивных практик предвыборного дискурса привлекает все большее число лингвистов в последние десятилетия, так как существенно расширяет стандартное представление об исследовании коммуникативных характеристик высказываний, реализованных в различных сферах деятельности (Романов 1988).

Отправной посылкой исследования является представление предвыборных высказываний-угроз как менасивных регулятивных действий или менасивных регулятивов, направленных на решение глобальной коммуникативной задачи политика - побуждения избирателей проголосовать за его кандидатуру — и маркированных различными языковыми средствами (Новоселова 2019). С позиций деятельного подхода к общению, который ставит во главу угла положение о практическом характере языка как инструмента для достижения определенных целей (Романов 1988: 4-5), анализ прагматического содержания предвыборных менасивов направлен на установление и интерпретацию в них элементов, несущих информацию о намерениях или интенции говорящего, его позициях относительно внешней действительности и самого акта социальной и коммуникативной деятельности, так как любое высказывание, как продукт речевой деятельности, выступает в виде инструмента или средства при воздействии на адресата для решения определенной языковой задачи (Кацнельсон 1972: 110; Леонтьев А.Н. 1977: 212-214; Гарпушкин 1977: 136; Леонтьев А.А. 1979: 26).

Также в работе использовались общенаучные методы, которые находятся в русле современной политической лингвистики и связаны с категоризацией вербальной репрезентации коммуникативного намерения собеседников в социальной интеракции, методы когнитивного картирования содержания высказываний-угроз предвыборного дискурса (подробнее об использовании данного метода для анализа политической коммуникации см.: Романов 2002: 13-177). Кроме того, в настоящем исследовании задействованы элементы количественного анализа, позволившие охарактеризовать частотность 
реализации в российском предвыборном дискурсе тех или иных разновидностей высказываний со значением угрозы.

\section{3. Адресатная направленность консеквентного компонента предвыборных менасивов}

В программных материалах кандидатов на пост Президента Российской Федерации 2018 года зафиксировано 229 менасивных регулятивов (высказываний), направленных на побуждение избирателей к голосованию за определенную кандидатуру при упоминании различных негативных фактов, событий, санкций и последствий (Новоселова 2019: 391). Не вызывает сомнений, что менасивные регулятивные действия, реализованные в предвыборных программах, адресованы избирателям, так как такие действия являются непосредственной составляющей предвыборной программы политика и участвуют в реализации глобальной коммуникативной цели политика - оказание определенного прагма-эмоционального воздействия на избирателя для того, чтобы повлиять на него, убедить в своей правоте и, следовательно, побудить проголосовать за свою кандидатуру.

Несмотря на то, что избиратель выступает в качестве адресата предвыборных высказываний со значением угрозы, важно обратить внимание на такой прагматический параметр как адресатная направленность следственного (консеквентного) компонента высказываний-угроз (подробнее о семантической структуре высказываний-угроз см.: Романов, Новоселова 2013: 61-69). С позиций деятельного подхода к общению выбранный прагматический параметр представляется логичным учитывать при оценке прагма-эмоционального воздействия менасивов на избирателей, так как направленность следственного (консеквентного) компонента высказываний-угроз в адрес той или иной группы населения способна производить определенное прагма-эмоциональное воздействие на избирателей.

Эмпирический материал даёт основание предполагать, что консеквентный компонент (а именно возможное наказание или санкция) предвыборных высказываний-угроз может содержать указание на определенные негативные последствия как для фокусной аудитории, т.е. для потенциальных избирателей, так и для представителей оппозиции, нефокусной аудитории, т.е. не-избирателей. Из сказанного следует, что признак адресатной направленности консеквентного компонента способен делить все предвыборные менасивы на две группы: 1) высказывания-угрозы с негативными последствиями для избирателей и 2) высказывания-угрозы с негативныли последствиями для не-избирателей. Также возможно использование понятия «адресатная разновидность высказываний-угроз», которое включает в свой содержательный объем обозначенные группы высказываний.

Выделенные две группы высказываний-угроз характеризуются различной частотностью реализации в предвыборных программах политиков. На материале исследования зафиксировано умеренное количество высказываний- 
угроз первой группы. Так, только 42 высказывания со значением угрозы, что составляет около 18,34 \% от общего количества примеров, содержат указание на негативные последствия для избирателей. Например: (4) Нельзя допустить, чтобы Россия отстала ещуе на один технологический ичикл и превратилась в мировое захолустье (Явлинский); (5) Mь должны жить согласно общеевропейским законам и иенностям - именно такой путь обеспечит нам и независимость, и процветание (Собчак); (6) Отставание, которое будет неизбежно усиливаться, если ничего не делать, - вот главная угроза, вот наш враг» (Путин); (7) Понятно, что этот путь будет сложньми и длительным. Но отказ от такого поворота равнозначен отказу от будущего (Явлинский); (8) Власть активно переходит кмеждународному олигархату, который по законам эволючии, обязательно приведёт к тотальному электронно-техническому контролю и всеобщему экономическому рабству» (Бабурин); (9) Революции и потрясения к нужному результату не приведут, все, что они могут - это спровоцировать либо новый передел собственности с хаосом, который мы уже проходили, либо резкий поворот в сторону левого тоталитаризма (Титов) и др.

Авторы представленных высказываний (4) - (9) информируют массового адресата о сложной ситуации в стране, а также сообщают о том, что эта ситуация может ухудшиться, если избиратели не будут активно участвовать в политической жизни страны и не выберут на пост Президента Российской Федерации кандидата, который сможет принять решения, связанные с улучшением качества жизни, стабилизацией экономической ситуации и урегулированием внешнеполитических конфликтов. Конечно, высказывания-угрозы используются политиком не для перечисления возможных санкций для избирателей с целью их запугивания, а для того, чтобы продемонстрировать им возможное наступление негативных последствий в случае предпочтения другого кандидата на выборах и побудить тем самым проголосовать за свою кандидатуру. В этой связи можно утверждать, что функционально-семантической особенностью высказываний-угроз с негативными последствиями для избирателей является их превентивный характер, направленный на то, чтобы уберечь избирателей от наступления негативных последствий и выбора «неправильного» кандидата.

Обращает на себя внимание тот факт, что высказывания-угрозы с негативными последствиями для избирателей присутствуют в предвыборных программах практически всех кандидатов на пост Президента Российской Федерации в 2018 году, за исключением программных материалов Павла Грудинина. Примечательно и то, что политики задействовали различное количество высказываний-угроз с негативными последствиями для избирателей: от 1 высказывания, зафиксированного в предвыборной программе Максима Сурайкина, до 16 высказываний в программных материалах Григория Явлинского, который явился бесспорным лидером по количеству высказыванийугроз в предвыборной программе и по количеству высказываний-угроз с негативными последствиями для избирателей. 
Важно отметить, что наряду с реализацией высказываний-угроз с негативными последствиями для избирателей все участники предвыборного дискурса активно использовали вторую разновидность менасивов. Материал исследования насчитывает 187 высказываний-угроз (что составляет около $81,66 \%$ от общего количества примеров) с негативными последствиями для не-избирателей, для нефокусной аудитории или третьих лиц. Приведенные данные позволяют утверждать, что такая адресатная разновидность высказываний-угроз является более востребованной в программных материалах политика для привлечения внимания и голосов избирателей. Например: (10) Повысить ответственность за нарушение прав потребителей (Явлинский); (11) Будут приняты срочные меры по регулированию банковской системы (Бабурин); (12) Мы ударим по рукам спекулянтам, по т.н. посредникам, которые не дают сельскому труженику выйти со своей продукиией на массового потребителя напрямую (Сурайкин).

В этой связи представляется возможным говорить о том, что вербальная манифестация угрозы, содержащей указание на негативные последствия для представителей нефокусной аудитории, ориентирована на формирование у избирателей образа политика, который понимает интересы электората и готов решать существующие проблемы, например: (13) Его источником долэно стать введение «природной рентыл в виде изъятия части сверхприбыли у добывающих компаний (Бабурин); (14) Создать госкомиссию по расследованию разграбления страны после 1991 года (Жириновский). Авторы представленных менасивов (13) и (14) понимают, что в стране много недовольных сверхприбылью добывающих компаний и итогами приватизации 1991 года, поэтому декларирование политиком возможных негативных последствий для граждан (представителей предприятий) с большими доходами выполняет роль аттрактантов избирателей.

Функционально-семантическая особенность предвыборных высказываний-угроз с негативными последствиями для не-избирателей заключается в том, что политик как автор таких высказываний стремится продемонстрировать фокусной аудитории свое намерение принимать участие в жизни избирателей, понимание необходимости решения экономических, социальных и внешнеполитических проблем, а также свою готовность бороться с общим «врагом» в лице представителей оппозиции, действующей власти, чиновников, нечестных бизнесменов, нарушителей законности и др. Поэтому со всей уверенностью можно утверждать, что высказывания-угрозы с негативными последствиями для не-избирателей несут обвинительное значение, являясь демонстративно категоричными менасивами.

Высказывания-угрозы с негативными последствиями для не-избирателей зафиксированы в программных материалах каждого из кандидатов на пост Президента Российской Федерации в 2018 году. Данная группа менасивов не является однородной, а включает 17 адресатных разновидностей высказываний-угроз, выделенных на основе более дробного структурирования 
направленности их консеквентного компонента. При этом очевидно, что некоторые разновидности высказываний-угроз являются наиболее актуальными для программных материалов политиков-кандидатов.

\section{4. Актуальные адресатные разновидности предвыборных менасивов}

Самыми актуальными для российского предвыборного дискурса стали высказывания-угрозы с негативными последствиями для представителей действующей власти, чиновников, представителей госаппарата, руководителей государственных (в том числе силовых) структур, например: (15) Президент, который будет ... подавлять, используя всю мощь государственной машины, правящий класс, эксплуататоров (Сурайкин); (16) Ликвидировать органы политического сыска (иентры по борьбе с экстремизмом) (Явлинский); (17) Необходимо ограничить пребывание любого избираемого должностного лица всех уровней исполнительной власти на одной должности двумя установленными законом сроками в течение жизни (Собчак). Такая адресатная разновидность менасивных высказываний встречается в программных материалах семи претендентов на пост Президента Российской Федерации, она является самой частной в российском предвыборном дискурсе, так как насчитывает 71 высказывание, что составляет около $31,00 \%$ от общего количества примеров. Обращает внимание, что в программных материалах Владимира Путина не использовались высказывания-угрозы указанной адресатной разновидности, так как во время предвыборной кампании политик являлся действующим Президентом Российской Федерации.

В предвыборных программах семи кандидатов на пост Президента Российской Федерации отмечена разновидность высказываний-угроз с негативными последствиями для нарушителей законности или нормативных требований. Разновидность представлена 32 высказываниями, что составляет примерно 13,97 \% от общего количества предвыборных менасивов. Высказывания такой разновидности отмечены в программных материалах семи политиков - Григория Явлинского, Владимира Жириновского, Максима Сурайкина, Сергея Бабурина, Ксении Собчак, Павла Грудинина и Владимира Путина, например: (18) За наглье выходки на дорогах - конфискация автомобиля и высылка водителя-хама на поселение за 300 км от дома (Жириновский); (19) Mbl вернем ГОСТы и введем уголовную ответственность за фальсификацию продуктов питания (Грудинин); (20) Снести все строения, возведенные с нарушением законодательства в природоохранных зонах и на берегах водоемов (Явлинский) и др.

Достаточно регулярными для российского предвыборного дискурса 2018 года оказались высказывания-угрозы с негативными последствиями для граждан с большими доходами или для прибыльных (в том числе монопольнblx) предприятий. Разновидность высказываний насчитывает 16 случаев реализации, что составляет около 6,98\% от общего количества примеров, и используются в программных материалах семи политиков - Григория 
Явлинского, Сергея Бабурина, Павла Грудинина, Владимира Жириновского, Ксении Собчак, Максима Сурайкина и Бориса Титова. Например: (21) Прогрессивная система налогообложения с освобождением от уплаты налогов малоимущих и повышением ставок на доходы сверхбогатых (Бабурин); (22) Ввести налог на сверхдоходы, освободив от уплаты подоходного налога всех, кто получает до 20 тысяч рублей (Жириновский); (23) Ввести единовременный компенсачионный налог на сверхкрупные доходы, полученные от приватизачии государственных активов в ходе залоговых аукционов (Явлинский); (24) Своим указом вводит временно, до принятия нового налогового законодательства, прогрессивную шкалу налогообложения для всех лии, имеющих доходы свыше 1 млн. рублей ежемесячно (Сурайкин) и др.

В пяти предвыборных программах зафиксировано 16 высказыванийугроз с негативными последствиями для нечестных бизнесменов или работодателей. Несомненным лидером по использованию указанной разновидности менасивов является Сергей Бабурин, в предвыборной программе которого обнаружено 6 таких высказываний, например: (25) Решение задачи по формированию широкого национально-патриотического движения, способного развернуть страну в сторону самостоятельного пути развития государства и гражданина, надо начать с решительной борьбы с бедностью и против безнравственного обогащения за счет народа (Бабурин). Несмотря на то, что разновидность высказываний-угроз с негативными последствиями для нечестных бизнесменов или работодателей составляет около 6,98 \% от общего числа примеров, она является достаточно актуальной для предвыборного дискурса и встречается не только в программе Сергея Бабурина, но у Григория Явлинского, Павла Грудинина, Максима Сурайкина и Владимира Жириновского.

Также востребована кандидатами на пост Президента Российской Федерации адресатная разновидность высказываний-угроз с негативными последствиями для тех, кто поддерживает коррупџию и коррупционеров. Эта разновидность менасивов охватывает 15 высказываний или около 6,55 \% от общего количества примеров и зафиксирована в предвыборных программах пяти кандидатов - Григория Явлинского, Ксении Собчак, Сергея Бабурина, Максима Сурайкина и Павла Грудинина. Например: (26) Пресечение корруnичи не на словах, а на деле даст и экономический, и морально-политический эффект (Грудинин); (27) Осуществить гласное и публичное расследование всех фактов коррупции в правительстве, администрации президента, правоохранительных органах, госкомпаниях и госкорпорациях (Явлинский).

Широко употребляемыми можно назвать высказывания-угрозы с негативными последствиями для стран-агрессоров, а также для государств, не выполняющих законодательство и взятых на себя обязательств. Такие менасивы задействованы в шести предвыборных программах и насчитывают 9 примеров, что составляет примерно $3,93 \%$ от общего количества высказываний-угроз. В частности, Владимир Путин использовал 4 менасива 
указанной разновидности, а Сергей Бабурин, Павел Грудинин, Владимир Жириновский, Максим Сурайкин и Григорий Явлинский - по одному менасиву. Например: (28) Все работы по обновлению наших оборонных систем проводятся строго в рамках действующих соглашений. Россия никому не угрожает (Путин); (29) Неукоснительно требовать возращения долгов с иностранных государств (Явлинский).

Исследование адресатной направленности консеквентного компонента предвыборных высказываний-угроз свидетельствует о том, что политики стратегически задействуют в своих программах, как правило, несколько адресатных разновидностей менасивов. При этом они чаще используют разновидности предвыборных высказываний-угроз:

- с негативными последствиями для представителей действующей власти, чиновников, представителей госаппарата, руководителей государственных (в том числе силовых) структур (около 31,00 \% от общего количества предвыборных высказываний-угроз);

- с негативными последствиями для избирателей (около 18,34 \% от общего количества предвыборных высказываний-угроз);

- с негативными последствиями для нарушителей законности или нормативных требований (около 13,97\% от общего количества предвыборных высказываний-угроз);

- с негативными последствиями для граждан с большими доходами и для прибыльных (в том числе монопольных) предприятий (около 6,98 \% от общего количества предвыборных высказываний-угроз);

- с негативными последствиями для нечестных бизнесменов или работодателей (около 6,98 \% от общего количества предвыборных высказываний-угроз);

- с негативными последствиями для тех, кто поддерживает коррупцию и коррупционеров (около 6,55 \% от общего количества предвыборных высказываний-угроз);

- с негативными последствиями для стран-агрессоров, а также для государств, не выполняющих законодательство и взятых на себя обязательств (около 3,93 \% от общего количества предвыборных высказыванийугроз).

Приведенные данные свидетельствуют о том, что семь перечисленных разновидностей высказываний-угроз являются в большей степени актуальными для российского предвыборного дискурса 2018 года, так как именно эти разновидности политики используют в своих программных материалах наиболее часто, решая стратегическую задачу оказания прагма-эмоционального воздействия на избирателей. При этом, если посчитать количество высказываний-угроз, которые относятся к указанным разновидностям, то получим 201 менасивное высказывание, что составляет около 87,77 \% от общего количества примеров (см. табл. 1). Иначе говоря, представленные семь адресатных разновидностей высказываний-угроз являются не только 
наиболее частотными для программных материалов кандидатов на пост Президента Российской Федерации в 2018 году, но и составляют основу прагма-эмоциионального воздействия их предвыборного дискурса.

\section{5. Нерегулярные адресатные разновидности предвыборных менасивов}

Помимо обозначенных высказываний-угроз в российском предвыборном дискурсе реализуются нерегулярные или второстепенные разновидности менасивов, выделяемые на основе адресатной направленности их консеквентного компонента. Такие адресатные разновидности пронумерованы в табл. 1 цифрами от 8 до 18 и насчитывают 28 высказываний или около 12,22 \% от общего количества примеров. В их число входят:

- высказывания-угрозы с негативными последствиями для представителей банковской системы, например: (30) Учреждение Государственного банка России и упразднение «филиала Международного валютного фонда» в виде Центрального банка России (Бабурин); (31) Своим указом Сталинский Президент-коммунист обнуляет процентную ставку рефинансирования и приостанавливает деятельность всех коммерческих банков, временно ограничивает хождение иностранной валюты внутри страны 500-та условными единицами в месяц в расчете на каждого гражданина (Сурайкин) и др.;

- высказывания-угрозы с негативными последствиями для тех, кто ничего не делает для развития страны или препятствует ее развитию, например: (32) Нужно отправить на заслуженный отдых тех, кто живет прошльм, прекратить раскачивать лодку, в которой мы все находимся и которая называется «планета Земля» (Путин) и др.;

- высказывания-угрозы с негативными последствиями для религиозных организаций, например: (33) ... своим указом обязывает все религиозные организации вернуть в собственность государства любое недвижимое имущество, ранее принадлежавщее государству и переданное церкви после 1991-го года, а также лишает религиозные институты всех налоговых льгот и экономических преференций (Сурайкин); (34) Создать предпосылки для вытеснения антимодернизационных разновидностей исламистской идеологии, опираясь при этом на умеренные версии ислама, пропагандирующуие модернизационные цуенности и предполагающие встраивание мусульман в современное общество (Явлинский) и др.;

- высказывания-угрозы с негативными последствиями для представителей СМИ, а также для тех, кто распространяет недостоверную (фальшивую) информацию, например: (35) Повысить ответственность должностных лич государственных и муниципальных органов за распространение недостоверной информаџчи в СМИ и в ответах на обращения граждан и организаџий (Явлинский) и др.;

- высказывания-угрозы с негативными последствиями для представителей ЖКХ, например: (36) В сфере жилищун-коммунального хозяйства необ- 
ходимо кардинальное усиление ответственности организаций и специилистов, занятых обеспечением нормальной жизнедеятельности сферы ЖКХ, жесткий государственный контроль за деятельностью управляющих компаний, ограничение их всевластия по отношению к жильцам (Бабурин); (37) Своим указом приостанавливает деятельность частных жилищных управляющих кампаний, вернув весь жилой фонд в ведение муниципалитетов, и обязывает высчитыввать тарифы ЖКХ для каждой семьи исходя из не более чем 10\% совокупного дохода данной семьи (Сурайкин) и др.;

- высказывания-угрозы с негативными последствиями для представителей судопроизводства или судебной власти, например: (38) Лишить председателей судов влияния на процесс назначения и отстранения судей (Явлинский) и др.;

- высказывания-угрозы с негативными последствиями для представителей (руководства) образовательных учреждений, например: (39) Mbl предлагаем сокращение числа вузов с государственной аккредитаџчей за счет усиления требований к их работе с иелью повышения качества высшего образования, поощрение интеграции российских университетов с институтами Академии наук, ведущими НИИ и КБ, с зарубежными университетами через программы подготовки студентов с двойными дипломами, а также расиирение практики предоставления государством льготных образовательных кредитов (Собчак) и др.;

- высказывания-угрозы с негативными последствиями для представителей международных запрещенных организаций или поддерживающих их граждан, например: (40) Вместе мы способны эффективно бороться с терроризмом и распространением оружия массового уничтожения, сдерживать притязания отдельных держав на мировую гегемонию, создать систему взаимной гарантированной защиты (Явлинский) и др.;

- высказывания-угрозы с негативными последствиями для тех, кто незаконно использует чужую интеллектуальную собственность, например: (41) Обеспечить действенную защиту интеллектуальной собственности и лишение научных степеней лиц, защзитивших диссертациии с выявленным плагиатом, независимо от срока давности (Явлинский) и др.;

- высказывания-угрозы с негативными последствиями для представителей оппозиции, например: (42) ...своим указом лишает государственных наград, званий и государственной поддержки их творчества тех представителей российской художественной интеллигенциии, кто в период с 1985 г. По настоящее время неоднократно публично выступал с клеветническими заявлениями в отношении СССР, сощиализма, советского народа! (Сурайкин) и др.;

- высказывания-угрозы с негативными последствиями для группы лиц, массового адресата, например: (43) Mbl НАЦИОНАЛИЗИРУЕМ и передадим ПОД КОНТРОЛЬ СОВЕТСКОГО ПРАВИТЕЛЬСТВА: банковскую систему; 
базовые отрасли реального сектора экономики железнодорожный транспорт; жилищьн-коммунальное хозяйство; учреждения здравоохранения и образования; будет введена государственная монополия на винно-водочную и табачную продукциюю (Сурайкин) и др.

Предложенная табл. 1 содержит сведения о частотности реализации высказываний-угроз с различной адресатной направленностью консеквентного компонента в российском предвыборном дискурсе 2018 года:

таблича 1

Адресатные разновидности предвыборных высказываний-угроз

\begin{tabular}{|c|c|c|c|c|}
\hline $\begin{array}{l}\text { № } \\
\Pi \backslash \Pi\end{array}$ & $\begin{array}{c}\text { Адресатные разновидности } \\
\text { высказываний-угроз }\end{array}$ & $\begin{array}{c}\text { Кол- } \\
\text { во } \\
\text { при- } \\
\text { меров }\end{array}$ & $\begin{array}{c}\text { Доля от общего } \\
\text { кол-ва менасивных } \\
\text { высказываний } \\
\text { российского } \\
\text { предвыборного } \\
\text { дискурса } \\
\end{array}$ & $\begin{array}{c}\text { Политики, которые } \\
\text { использовали адресатные } \\
\text { разновидности } \\
\text { высказываний-угроз } \\
\text { (кол-во высказываний-угроз) }\end{array}$ \\
\hline 1 & $\begin{array}{l}\text { Высказывания-угрозы с нега- } \\
\text { тивными последствиями } \\
\text { для избирателей }\end{array}$ & 42 & $18,34 \%$ & $\begin{array}{l}\text { Все участники предвыбор- } \\
\text { ного дискурса, кроме } \\
\text { Павла Грудинина }\end{array}$ \\
\hline 1 & $\begin{array}{l}\text { Высказывания-угрозы с нега- } \\
\text { тивными последствиями } \\
\text { для избирателей }\end{array}$ & 42 & $18,34 \%$ & $\begin{array}{l}7 \text { политиков: } \\
\text { Григорий Явлинский (16) } \\
\text { Борис Титов (8) } \\
\text { Сергей Бабурин (6) } \\
\text { Ксения Собчак (5) } \\
\text { Владимир Путин (4) } \\
\text { Владимир Жириновский (2) } \\
\text { Максим Сурайкин (1) } \\
\end{array}$ \\
\hline II & $\begin{array}{l}\text { Высказывания-угрозы с нега- } \\
\text { тивными последствиями } \\
\text { для не-избирателей }\end{array}$ & 187 & $81,66 \%$ & Все политики-кандидаты \\
\hline 2 & $\begin{array}{l}\text { Высказывания-угрозы с нега- } \\
\text { тивными последствиями для } \\
\text { представителей действующей } \\
\text { власти, чиновников, представи- } \\
\text { телей госаппарата, руководите- } \\
\text { лей государственных (в том } \\
\text { числе силовых) структур }\end{array}$ & 71 & $31,00 \%$ & $\begin{array}{l}7 \text { политиков: } \\
\text { Григорий Явлинский (35) } \\
\text { Максим Сурайкин (13) } \\
\text { Ксения Собчак (12) } \\
\text { Сергей Бабурин (7) } \\
\text { Владимир Жириновский (3) } \\
\text { Борис Титов (1) }\end{array}$ \\
\hline 3 & $\begin{array}{l}\text { Высказывания-угрозы с нега- } \\
\text { тивными последствиями для } \\
\text { нарушителей законности или } \\
\text { нормативных требований }\end{array}$ & 32 & $13,97 \%$ & $\begin{array}{l}7 \text { политиков: } \\
\text { Григорий Явлинский (13) } \\
\text { Владимир Жириновский (7) } \\
\text { Максим Сурайкин (6) } \\
\text { Сергей Бабурин (2) } \\
\text { Ксения Собчак (2) } \\
\text { Павел Грудинин (1) } \\
\text { Владимир Путин (1) }\end{array}$ \\
\hline
\end{tabular}




\begin{tabular}{|c|c|c|c|c|}
\hline $\begin{array}{l}\text { № } \\
\text { п\п }\end{array}$ & $\begin{array}{c}\text { Адресатные разновидности } \\
\text { высказываний-угроз }\end{array}$ & $\begin{array}{c}\text { Кол- } \\
\text { во } \\
\text { при- } \\
\text { меров }\end{array}$ & \begin{tabular}{|c|} 
Доля от общего \\
кол-ва менасивных \\
высказываний \\
российского \\
предвыборного \\
дискурса \\
\end{tabular} & $\begin{array}{c}\text { Политики, которые } \\
\text { использовали адресатные } \\
\text { разновидности } \\
\text { высказываний-угроз } \\
\text { (кол-во высказываний-угроз) }\end{array}$ \\
\hline 4 & $\begin{array}{l}\text { Высказывания-угрозы с нега- } \\
\text { тивными последствиями } \\
\text { для граждан с большими } \\
\text { доходами или для прибыльных } \\
\text { (в том числе монопольных) } \\
\text { предприятий }\end{array}$ & 16 & $6,98 \%$ & $\begin{array}{l}7 \text { политиков: } \\
\text { Григорий Явлинский (5) } \\
\text { Сергей Бабурин (2) } \\
\text { Павел Грудинин (2) } \\
\text { Владимир Жириновский (2) } \\
\text { Ксения Собчак (2) } \\
\text { Максим Сурайкин (2) } \\
\text { Борис Титов (1) }\end{array}$ \\
\hline 5 & $\begin{array}{l}\text { Высказывания-угрозы с нега- } \\
\text { тивными последствиями } \\
\text { для нечестных бизнесменов } \\
\text { или работодателей }\end{array}$ & 16 & $6,98 \%$ & $\begin{array}{l}5 \text { политиков: } \\
\text { Сергей Бабурин (6) } \\
\text { Григорий Явлинский (5) } \\
\text { Павел Грудинин (2) } \\
\text { Максим Сурайкин (2) } \\
\text { Владимир Жириновский (1) }\end{array}$ \\
\hline 6 & $\begin{array}{l}\text { Высказывания-угрозы с нега- } \\
\text { тивными последствиями } \\
\text { для тех, кто поддерживает кор- } \\
\text { рупцию и коррупционеров }\end{array}$ & 15 & $6,55 \%$ & $\begin{array}{l}5 \text { политиков: } \\
\text { Григорий Явлинский (7) } \\
\text { Ксения Собчак (3) } \\
\text { Сергей Бабурин (2) } \\
\text { Максим Сурайкин (2) } \\
\text { Павел Грудинин (1) } \\
\end{array}$ \\
\hline 7 & $\begin{array}{l}\text { Высказывания-угрозы с нега- } \\
\text { тивными последствиями } \\
\text { для стран-агрессоров, а также } \\
\text { для государств, не выполняю- } \\
\text { щих законодательство } \\
\text { и взятых на себя обязательств }\end{array}$ & 9 & $3,93 \%$ & $\begin{array}{l}6 \text { политиков: } \\
\text { Владимир Путин (4) } \\
\text { Сергей Бабурин (1) } \\
\text { Павел Грудинин (1) } \\
\text { Владимир Жириновский (1) } \\
\text { Максим Сурайкин (1) } \\
\text { Григорий Явлинский (1) }\end{array}$ \\
\hline 8 & $\begin{array}{l}\text { Высказывания-угрозы с нега- } \\
\text { тивными последствиями } \\
\text { для представителей банковской } \\
\text { системы }\end{array}$ & 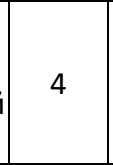 & $1,74 \%$ & $\begin{array}{l}2 \text { политика: } \\
\text { Сергей Бабурин (2) } \\
\text { Максим Сурайкин (2) }\end{array}$ \\
\hline 9 & $\begin{array}{l}\text { Высказывания-угрозы с нега- } \\
\text { тивными последствиями } \\
\text { для тех, кто ничего не делает } \\
\text { для развития страны } \\
\text { или препятствует ее развитию } \\
\end{array}$ & 4 & $1,74 \%$ & $\begin{array}{l}2 \text { политика: } \\
\text { Владимир Путин (3) } \\
\text { Владимир Жириновский (1) }\end{array}$ \\
\hline 10 & $\begin{array}{l}\text { Высказывания-угрозы с нега- } \\
\text { тивными последствиями } \\
\text { для религиозных организаций }\end{array}$ & 3 & $1,31 \%$ & $\begin{array}{l}2 \text { политика: } \\
\text { Максим Сурайкин (2) } \\
\text { Григорий Явлинский (1) }\end{array}$ \\
\hline 11 & \begin{tabular}{|l|} 
Высказывания-угрозы с нега- \\
тивными последствиями \\
для представителей СМИ, \\
а также для тех, кто распростра- \\
няет недостоверную (фальши- \\
вую) информацию \\
\end{tabular} & 3 & $1,31 \%$ & $\begin{array}{l}2 \text { политика: } \\
\text { Максим Сурайкин (2) } \\
\text { Григорий Явлинский (1) }\end{array}$ \\
\hline
\end{tabular}




\begin{tabular}{|c|c|c|c|c|}
\hline $\begin{array}{l}\text { № } \\
\Pi \backslash \pi\end{array}$ & $\begin{array}{c}\text { Адресатные разновидности } \\
\text { высказываний-угроз }\end{array}$ & $\begin{array}{c}\text { Кол- } \\
\text { во } \\
\text { при- } \\
\text { меров }\end{array}$ & $\begin{array}{c}\text { Доля от общего } \\
\text { кол-ва менасивных } \\
\text { высказываний } \\
\text { российского } \\
\text { предвыборного } \\
\text { дискурса }\end{array}$ & $\begin{array}{c}\text { Политики, которые } \\
\text { использовали адресатные } \\
\text { разновидности } \\
\text { высказываний-угроз } \\
\text { (кол-во высказываний-угроз) }\end{array}$ \\
\hline 12 & $\begin{array}{l}\text { Высказывания-угрозы с нега- } \\
\text { тивными последствиями } \\
\text { для представителей ЖкX }\end{array}$ & 2 & $0,87 \%$ & $\begin{array}{l}2 \text { политика: } \\
\text { Сергей Бабурин (1) } \\
\text { Максим Сурайкин (1) }\end{array}$ \\
\hline 13 & $\begin{array}{l}\text { Высказывания-угрозы с нега- } \\
\text { тивными последствиями } \\
\text { для представителей судопроиз- } \\
\text { водства или судебной власти }\end{array}$ & 2 & $0,87 \%$ & $\begin{array}{l}2 \text { политика: } \\
\text { Ксения Собчак (1) } \\
\text { Григорий Явлинский (1) }\end{array}$ \\
\hline 14 & $\begin{array}{l}\text { Высказывания-угрозы с нега- } \\
\text { тивными последствиями } \\
\text { для представителей (руковод- } \\
\text { ства) образовательных } \\
\text { учреждений } \\
\end{array}$ & 2 & $0,87 \%$ & $\begin{array}{l}1 \text { политик: } \\
\text { Ксения Собчак (2) }\end{array}$ \\
\hline 15 & $\begin{array}{l}\text { Высказывания-угрозы с нега- } \\
\text { тивными последствиями } \\
\text { для представителей междуна- } \\
\text { родных запрещенных организа- } \\
\text { ций или поддерживающих их } \\
\text { граждан }\end{array}$ & 2 & $0,87 \%$ & $\begin{array}{l}1 \text { политик: } \\
\text { Григорий Явлинский (2) }\end{array}$ \\
\hline 16 & $\begin{array}{l}\text { Высказывания-угрозы с нега- } \\
\text { тивными последствиями } \\
\text { для тех, кто незаконно } \\
\text { использует чужую интеллекту- } \\
\text { альную собственность }\end{array}$ & 2 & $0,87 \%$ & $\begin{array}{l}1 \text { политик: } \\
\text { Григорий Явлинский (2) }\end{array}$ \\
\hline 17 & $\begin{array}{l}\text { Высказывания-угрозы с нега- } \\
\text { тивными последствиями } \\
\text { для представителей оппозиции }\end{array}$ & 2 & $0,87 \%$ & $\begin{array}{l}2 \text { политика: } \\
\text { Максим Сурайкин (1) } \\
\text { Борис Титов (1) }\end{array}$ \\
\hline 18 & $\begin{array}{l}\text { Высказывания-угрозы с нега- } \\
\text { тивными последствиями } \\
\text { для группы лиц, массового ад- } \\
\text { ресата }\end{array}$ & 2 & $0,87 \%$ & $\begin{array}{l}1 \text { политик: } \\
\text { Максим Сурайкин (2) }\end{array}$ \\
\hline
\end{tabular}

Примечание. В скобках после фамилии политика указано количество менасивных высказываний той или иной адресатной разновидностей в его предвыборной программе.

Table 1

Targeted types of pre-election threat statements

\begin{tabular}{|c|c|c|c|c|}
\hline № & $\begin{array}{c}\text { Targeted types of pre-election } \\
\text { threat statements }\end{array}$ & $\begin{array}{c}\text { Number of } \\
\text { threat } \\
\text { statements }\end{array}$ & $\begin{array}{c}\text { Percentage of the } \\
\text { total number of } \\
\text { threat statements } \\
\text { in Russian pre- } \\
\text { election discourse }\end{array}$ & $\begin{array}{c}\text { Politicians who used targeted } \\
\text { types of threat statements } \\
\text { (number of threat statements) }\end{array}$ \\
\hline $\mathbf{I}$ & $\begin{array}{l}\text { Threat statements with } \\
\text { negative effect on voters }\end{array}$ & $\mathbf{4 2}$ & $\mathbf{1 8 . 3 4 \%}$ & $\begin{array}{l}\text { All participants of pre-election } \\
\text { discourse, except } \\
\text { Pavel Grudinin }\end{array}$ \\
\hline
\end{tabular}




\begin{tabular}{|c|c|c|c|c|}
\hline № & $\begin{array}{c}\text { Targeted types of pre-election } \\
\text { threat statements }\end{array}$ & $\begin{array}{c}\text { Number of } \\
\text { threat } \\
\text { statements }\end{array}$ & $\begin{array}{l}\text { Percentage of the } \\
\text { total number of } \\
\text { threat statements } \\
\text { in Russian pre- } \\
\text { election discourse }\end{array}$ & $\begin{array}{c}\text { Politicians who used targeted } \\
\text { types of threat statements } \\
\text { (number of threat statements) }\end{array}$ \\
\hline 1 & $\begin{array}{l}\text { Threat statements with } \\
\text { negative effect on voters }\end{array}$ & 42 & $18.34 \%$ & $\begin{array}{l}7 \text { politicians: } \\
\text { Grigorii Yavlinskii (16) } \\
\text { Boris Titov (8) } \\
\text { Sergei Baburin (6) } \\
\text { Kseniya Sobchak (5) } \\
\text { Vladimir Putin (4) } \\
\text { Vladimir Zhirinovskii (2) } \\
\text { Maksim Suraikin (1) }\end{array}$ \\
\hline II & $\begin{array}{l}\text { Threat statements with } \\
\text { negative effect on non-voters } \\
\text { (unfocused audience) }\end{array}$ & 187 & $81.66 \%$ & All politicians \\
\hline 2 & $\begin{array}{l}\text { Threat statements with } \\
\text { negative effect on the } \\
\text { representatives of the } \\
\text { government, officials and } \\
\text { representatives of the state } \\
\text { apparatus }\end{array}$ & 71 & $31.00 \%$ & $\begin{array}{l}7 \text { politicians: } \\
\text { Grigorii Yavlinskii (35) } \\
\text { Maksim Suraikin (13) } \\
\text { Kseniya Sobchak (12) } \\
\text { Sergei Baburin (7) } \\
\text { Vladimir Zhirinovskii (3) } \\
\text { Boris Titov (1) }\end{array}$ \\
\hline 3 & $\begin{array}{l}\text { Threat statements with } \\
\text { negative effect on citizens } \\
\text { who break the law }\end{array}$ & 32 & $13.97 \%$ & $\begin{array}{l}7 \text { politicians: } \\
\text { Grigorii Yavlinskii (13) } \\
\text { Vladimir Zhirinovskii (7) } \\
\text { Maksim Suraikin (6) } \\
\text { Sergei Baburin (2) } \\
\text { Kseniya Sobchak (2) } \\
\text { Pavel Grudinin (1) } \\
\text { Vladimir Putin (1) }\end{array}$ \\
\hline 4 & $\begin{array}{l}\text { Threat statements with } \\
\text { negative effect on citizens } \\
\text { with high incomes or on } \\
\text { profitable (including } \\
\text { monopolistic) enterprises }\end{array}$ & 16 & $6.98 \%$ & $\begin{array}{l}7 \text { politicians: } \\
\text { Grigorii Yavlinskii (5) } \\
\text { Sergei Baburin (2) } \\
\text { Pavel Grudinin (2) } \\
\text { Vladimir Zhirinovskii (2) } \\
\text { Kseniya Sobchak (2) } \\
\text { Maksim Suraikin (2) } \\
\text { Boris Titov (1) }\end{array}$ \\
\hline 5 & $\begin{array}{l}\text { Threat statements with } \\
\text { negative effect on dishonest } \\
\text { businessmen or employers }\end{array}$ & 16 & $6.98 \%$ & $\begin{array}{l}5 \text { politicians: } \\
\text { Sergei Baburin (6) } \\
\text { Grigorii Yavlinskii (5) } \\
\text { Pavel Grudinin (2) } \\
\text { Maksim Suraikin (2) } \\
\text { Vladimir Zhirinovskii (1) } \\
\end{array}$ \\
\hline 6 & $\begin{array}{l}\text { Threat statements with } \\
\text { negative effect on citizens } \\
\text { who support corruption and } \\
\text { corrupt officials }\end{array}$ & 15 & $6.55 \%$ & $\begin{array}{l}\text { politicians: } \\
\text { Grigorii Yavlinskii (7) } \\
\text { Kseniya Sobchak (3) } \\
\text { Sergei Baburin (2) } \\
\text { Maksim Suraikin (2) } \\
\text { Pavel Grudinin (1) }\end{array}$ \\
\hline
\end{tabular}




\begin{tabular}{|c|c|c|c|c|}
\hline № & $\begin{array}{c}\text { Targeted types of pre-election } \\
\text { threat statements }\end{array}$ & $\begin{array}{l}\text { Number of } \\
\text { threat } \\
\text { statements }\end{array}$ & $\begin{array}{l}\text { Percentage of the } \\
\text { total number of } \\
\text { threat statements } \\
\text { in Russian pre- } \\
\text { election discourse }\end{array}$ & $\begin{array}{l}\text { Politicians who used targeted } \\
\text { types of threat statements } \\
\text { (number of threat statements) }\end{array}$ \\
\hline 7 & $\begin{array}{l}\text { Threat statements with } \\
\text { negative effect on countries- } \\
\text { aggressors }\end{array}$ & 9 & $3.93 \%$ & $\begin{array}{l}6 \text { politicians: } \\
\text { Vladimir Putin (4) } \\
\text { Sergei Baburin (1) } \\
\text { Pavel Grudinin (1) } \\
\text { Vladimir Zhirinovskii (1) } \\
\text { Maksim Suraikin (1) } \\
\text { Grigorii Yavlinskii (1) } \\
\end{array}$ \\
\hline 8 & $\begin{array}{l}\text { Threat statements with } \\
\text { negative effect on bankers }\end{array}$ & 4 & $1.74 \%$ & $\begin{array}{l}2 \text { politicians: } \\
\text { Sergei Baburin (2) } \\
\text { Maksim Suraikin (2) }\end{array}$ \\
\hline 9 & $\begin{array}{l}\text { Threat statements with } \\
\text { negative effect on those who } \\
\text { do nothing for the country's } \\
\text { development or hinders its } \\
\text { development }\end{array}$ & 4 & $1.74 \%$ & $\begin{array}{l}2 \text { politicians: } \\
\text { Vladimir Putin (3) } \\
\text { Vladimir Zhirinovskii (1) }\end{array}$ \\
\hline 10 & $\begin{array}{l}\text { Threat statements with } \\
\text { negative effect on religious } \\
\text { organizations }\end{array}$ & 3 & $1.31 \%$ & $\begin{array}{l}2 \text { politicians: } \\
\text { Maksim Suraikin (2) } \\
\text { Grigorii Yavlinskii (1) } \\
\end{array}$ \\
\hline 11 & $\begin{array}{l}\text { Threat statements with } \\
\text { negative effect on the media, } \\
\text { and also on the media with } \\
\text { fake news }\end{array}$ & 3 & $1.31 \%$ & $\begin{array}{l}2 \text { politicians: } \\
\text { Maksim Suraikin (2) } \\
\text { Grigorii Yavlinskii (1) }\end{array}$ \\
\hline 12 & \begin{tabular}{|l} 
Threat statements with \\
negative effect on \\
representatives of housing \\
and communal services \\
\end{tabular} & 2 & $0.87 \%$ & $\begin{array}{l}2 \text { politicians: } \\
\text { Sergei Baburin (1) } \\
\text { Maksim Suraikin (1) }\end{array}$ \\
\hline 13 & $\begin{array}{l}\text { Threat statements with } \\
\text { negative effect on judicial } \\
\text { authority }\end{array}$ & 2 & $0.87 \%$ & $\begin{array}{l}2 \text { politicians: } \\
\text { Kseniya Sobchak (1) } \\
\text { Grigorii Yavlinskii (1) } \\
\end{array}$ \\
\hline 14 & $\begin{array}{l}\text { Threat statements with } \\
\text { negative effect on } \\
\text { administration of } \\
\text { educational institutions }\end{array}$ & 2 & $0.87 \%$ & $\begin{array}{l}1 \text { politician: } \\
\text { Kseniya Sobchak (2) }\end{array}$ \\
\hline 15 & $\begin{array}{l}\text { Threat statements with } \\
\text { negative effect on } \\
\text { international outlawed } \\
\text { organizations or citizens } \\
\text { supporting them }\end{array}$ & 2 & $0.87 \%$ & $\begin{array}{l}1 \text { politician: } \\
\text { Grigorii Yavlinskii (2) }\end{array}$ \\
\hline 16 & $\begin{array}{l}\text { Threat statements with } \\
\text { negative effect on those } \\
\text { who illegally uses someone } \\
\text { else's intellectual property } \\
\end{array}$ & 2 & $0.87 \%$ & $\begin{array}{l}1 \text { politician: } \\
\text { Grigorii Yavlinskii (2) }\end{array}$ \\
\hline 17 & $\begin{array}{l}\text { Threat statements with } \\
\text { negative effect on the } \\
\text { opposition }\end{array}$ & 2 & $0.87 \%$ & $\begin{array}{l}2 \text { politicians: } \\
\text { Maksim Suraikin (1) } \\
\text { Boris Titov (1) }\end{array}$ \\
\hline
\end{tabular}




\begin{tabular}{|c|c|c|c|c|}
\hline № & $\begin{array}{c}\text { Targeted types of pre-election } \\
\text { threat statements }\end{array}$ & $\begin{array}{c}\text { Number of } \\
\text { threat } \\
\text { statements }\end{array}$ & $\begin{array}{c}\text { Percentage of the } \\
\text { total number of } \\
\text { threat statements } \\
\text { in Russian pre- } \\
\text { election discourse }\end{array}$ & $\begin{array}{c}\text { Politicians who used targeted } \\
\text { types of threat statements } \\
\text { (number of threat statements) }\end{array}$ \\
\hline 18 & $\begin{array}{l}\text { Threat statements with } \\
\text { negative effect on different } \\
\text { groups of persons or mass } \\
\text { addressee }\end{array}$ & 2 & $0.87 \%$ & $\begin{array}{l}1 \text { politician: } \\
\text { Maksim Suraikin (2) }\end{array}$ \\
\hline
\end{tabular}

Note. The number after the surname indicates the number of targeted types of threat statements in politician's pre-election program.

Отмеченные обстоятельства свидетельствуют о том, что политики целенаправленно используют высказывания-угрозы, декларирующие негативные последствия различным группам населения, пытаясь таким образом завоевать доверие и голоса избирателей. Эмпирический массив исследования показывает, что выбранная кандидатом разновидность (или разновидности) высказываний-угроз с той или иной адресатной направленностью консеквентного компонента не может определять прагма-эмоциональное воздействие его менасивного дискурса и предвыборной программы, так как политики-кандидаты используют практически один и тот же перечень адресатов консеквентных компонентов высказываний со значением угрозы. Логично бы предположить, что менасивы с негативными последствиями для избирателей будут способствовать предпочтению избирателями другого кандидата, не угрожающего им. Однако результаты выборов указывают на то, что кандидат, набравший наибольшее количество голосов на выборах - Владимир Путин (Результаты выборов президента России 2018, http://vibory-rf.ru, далее http://vibory-rf.ru), употребил 4 высказывания-угрозы с негативными последствиями для избирателей. При этом обращает на себя внимание тот факт, что кандидат, занявший второе место на выборах - Павел Грудинин, вообще не использовал в своей программе высказывания-угрозы, содержащие указание на негативные последствия для избирателей.

\section{6. Тенденции использования адресатных разновидностей предвыборных менасивов: результаты исследования}

На материале исследования нетрудно убедиться, что выбор политиком той или иной адресатной направленности консеквентных компонентов высказываний-угроз не оказывает влияния на прагма-эмоциональное воздействие его предвыборной программы и, следовательно, на количество набранных им голосов на выборах (http://vibory-rf.ru). Но в таком ракурсе рассуждений нельзя не обратить внимание на количество разновидностей высказыванийугроз с различной адресатной направленностью консеквентного компонента, которое задействуют политики в своих программных материалах. В частно- 
сти, перспективно проверить наличие какой-либо пропорциональной зависимости между количеством адресатных разновидностей высказываний-угроз того или иного политика и количеством набранных им голосов на выборах.

Следующий список содержит информацию о количественном объёме адресатных разновидностей предвыборных высказываний-угроз у кандидатов на пост Президента Российской Федерации, в котором политики расположены в порядке увеличения количества использованных ими разновидностей высказываний-угроз (номера разновидностей указаны согласно табл. 1):

Владимир Путин - 4 разновидности (№ 1, 3, 7, 9),

Борис Титов - 4 разновидности (№ 1, 2, 4, 17),

Павел Грудинин — 5 разновидностей (№ 3, 4, 5, 6, 7);

Владимир Жириновский - 7 разновидностей (№ 1, 2, 3, 4, 5, 7, 9);

Ксения Собчак -7 разновидностей (№ 1, 2, 3, 4, 6, 13, 14);

Сергей Бабурин — 9 разновидностей (№ 1, 2, 3, 4, 5, 6, 7, 8, 12);

Григорий Явлинский — 12 разновидностей (№ 1, 2, 3, 4, 5, 6, 7, 10, 11, 13 , $15,16)$;

Максим Сурайкин - 13 разновидностей (№ 1, 2, 3, 4, 5, 6, 7, 8, 10, 11, 12 , 17, 18).

Сравнивая результаты выборов Президента Российской Федерации (http://vibory-rf.ru) и данные об адресатных разновидностях высказыванийугроз в предвыборной программе того или иного политика, можно говорить об отсутствии прямой корреляционной связи между количеством адресатных разновидностей высказываний-угроз, задействованных политиком, и количеством набранных им голосов. Тем не менее, легко убедиться, что кандидат, набравший наибольшее количество голосов - Владимир Путин, использовал наименьшее количество разновидностей менасивов. В контексте сказанного заметим, что Павел Грудинин употребил 5 разновидностей предвыборных высказываний-угроз с различной адресатной направленностью консеквентного компонента и занял второе место среди кандидатов на пост Президента Российской Федерации как по количеству набранных голосов, так и по количеству адресатных разновидностей высказываний-угроз (см. табл. 2 и 3). Далее, отметим, что Владимир Жириновский, занявший 3-е место по итогам выборов, и Ксения Собчак, занявшая 4-е место на выборах, использовали по 7 разновидностей высказываний-угроз с различной адресатной направленностью консеквентного компонента и разделили 3 позицию в табл. 3. Примечательно и то, что по итогам выборов у Владимира Жириновского незначительный отрыв от Ксении Собчак в количестве набранных голосов избирателей.

Продолжая сопоставлять результаты выборов и количество разновидностей высказываний-угроз с различной адресатной направленностью консеквентного компонента в предвыборной программе того или иного политика, отметим, что Григорий Явлинский занял 5-е место на выборах и расположился на 5 позиции по количеству адресатных разновидностей менасивов, а 
Максим Сурайкин с небольшим отрывом от следующего за ним кандидата (Сергея Бабурина) занял 7-е место (т.е. оказался практически последним) на выборах и расположился на 6 (последней) позиции по количеству адресатных разновидностей менасивных высказываний, реализованных в предвыборной программе (см. табл. 2 и 3 ).

В табл. 2 находят отражение итоговые показатели выборов Президента Российской Федерации в 2018 году, а табл. 3 содержит информацию о количестве адресатных разновидностей высказываний-угроз, которые реализованы в предвыборных программах политиков-кандидатов:

таблица 2

Итоги выборов Президента Российской Федерации в 2018 году

\begin{tabular}{|c|c|c|c|}
\hline $\begin{array}{l}\text { № } \\
\Pi / \Pi\end{array}$ & Кандидат & $\begin{array}{c}\text { Процент } \\
\text { полученный } \\
\text { голосов, \% }\end{array}$ & $\begin{array}{c}\text { Кол-во } \\
\text { высказыва- } \\
\text { ний-угроз }\end{array}$ \\
\hline 1 & $\begin{array}{l}\text { Владимир } \\
\text { Путин }\end{array}$ & 76,6 & 12 \\
\hline 2 & Павел Грудинин & 11,8 & 7 \\
\hline 3 & $\begin{array}{l}\text { Владимир } \\
\text { Жириновский }\end{array}$ & 5,66 & 17 \\
\hline 4 & Ксения Собчак & 1,67 & 27 \\
\hline 5 & $\begin{array}{l}\text { Григорий } \\
\text { Явлинский }\end{array}$ & 1,04 & 89 \\
\hline 6 & Борис Титов & 0,76 & 11 \\
\hline 7 & $\begin{array}{l}\text { Максим } \\
\text { Сурайкин }\end{array}$ & 0,68 & 37 \\
\hline 8 & Сергей Бабурин & 0,65 & 29 \\
\hline
\end{tabular}

Количество адресатных разновидностей высказываний-угроз

\begin{tabular}{|c|l|c|}
\hline $\begin{array}{c}\text { № } \\
\text { п/п }\end{array}$ & \multicolumn{1}{|c|}{ Кандидат } & $\begin{array}{c}\text { Кол-во раз- } \\
\text { новидностей } \\
\text { высказыва- } \\
\text { ний-угроз }\end{array}$ \\
\hline 1 & $\begin{array}{l}\text { Владимир Путин / } \\
\text { Борис Титов }\end{array}$ & 4 \\
\hline 2 & Павел Грудинин & 5 \\
\hline 3 & $\begin{array}{l}\text { Владимир Жириновский / } \\
\text { Ксения Собчак }\end{array}$ & 7 \\
\hline 4 & Сергей Бабурин & 9 \\
\hline 5 & $\begin{array}{l}\text { Григорий } \\
\text { Явлинский }\end{array}$ & 12 \\
\hline 6 & $\begin{array}{l}\text { Максим } \\
\text { Сурайкин }\end{array}$ & 13 \\
\hline
\end{tabular}

Table 2

Election results

in the Russian Federation in $\mathbf{2 0 1 8}$

\begin{tabular}{|c|l|c|c|}
\hline № & \multicolumn{1}{|c|}{ Politician } & $\begin{array}{c}\text { The } \\
\text { percentage } \\
\text { of votes,\% }\end{array}$ & $\begin{array}{c}\text { Number of } \\
\text { threat } \\
\text { statements }\end{array}$ \\
\hline 1 & Vladimir Putin & 76.6 & 12 \\
\hline 2 & Pavel Grudinin & 11.8 & 7 \\
\hline 3 & $\begin{array}{l}\text { Vladimir } \\
\text { Zhirinovskii }\end{array}$ & 5.66 & 17 \\
\hline 4 & Kseniya Sobchak & 1.67 & 27 \\
\hline 5 & Grigorii Yavlinskii & 1.04 & 89 \\
\hline 6 & Boris Titov & 0.76 & 11 \\
\hline 7 & Maksim Suraikin & 0.68 & 37 \\
\hline 8 & Sergei Baburin & 0.65 & 29 \\
\hline
\end{tabular}

The number of targeted types of threat statements

\begin{tabular}{|c|l|c|}
\hline № & \multicolumn{1}{|c|}{ Politician } & $\begin{array}{c}\text { Number } \\
\text { of targeted } \\
\text { types of threat } \\
\text { statements }\end{array}$ \\
\hline 1 & $\begin{array}{l}\text { Vladimir Putin / } \\
\text { Boris Titov }\end{array}$ & 4 \\
\hline 2 & Pavel Grudinin & 5 \\
\hline 3 & $\begin{array}{l}\text { Vladimir Zhirinovskii / } \\
\text { Kseniya Sobchak }\end{array}$ & 7 \\
\hline 4 & Sergei Baburin & 9 \\
\hline 5 & Grigorii Yavlinskii & 12 \\
\hline 6 & Maksim Suraikin & 13 \\
\hline
\end{tabular}

Table 3 
Полученные результаты исследования позволяют выявить достаточное и необходимое количество адресатных разновидностей высказываний-угроз, которое способно оказывать запланированное политиком прагма-эмоциональное воздействие на избирателей. Обращает внимание, что в контексте российского предвыборного дискурса 2018 года реализация политиком чеmblpex разновидностей высказываний-угроз с различной адресатной направленностью консеквентного компонента явилась прагматически эффективным инструментом воздействия на избирателей. Материал исследования также фиксирует, что для политика угрожать внушительному количеству адресатов значит уменьшать воздействующий потенциал своей предвыборной программы. Ярким подтверждением сказанному является использование 13 адресатных разновидностей высказываний-угроз (из 18 возможных) в программных материалах Максима Сурайкина, который занял 7-е место по итогам выборов.

\section{7. Заключение}

В ходе исследования уделено внимание такому прагматическому параметру как адресатная направленность консеквентных компонентов предвыборных высказываний-угроз. Предложенный параметр выступил в качестве критерия распределения менасивов на две группы: 1) высказывания-угрозы с негативными последствиями для избирателей и 2) высказывания-угрозы с негативными последствиями для не-избирателей. Установлено, что выделенные две группы менасивов характеризуются различной частотностью реализации в программных материалах политиков: высказывания-угрозы первой группы насчитывают около 18,34 \% от общего количества примеров, а высказывания второй группы - около 81,66 \%. Приведенные данные позволяют утверждать, что в предвыборных программах политики целенаправленно отдают приоритет использованию высказываний-угроз с негативными последствиями для не-избирателей или нефокусной аудитории, пытаясь таким образом завоевать внимание и голоса избирателей.

Группа высказываний-угроз с негативными последствиями для не-избирателей сформирована 17 разновидностями менасивов, выделенных на основе более дробного структурирования адресатной направленности их консеквентного компонента. Полученный результат свидетельствует о том, что политик как автор предвыборной программы недостаточно хорошо знает предпочтения избирателей как массового адресата, их эмоциональное состояние и переживания, поэтому он ориентирует свое воздействие на широкий круг потенциальных избирателей и задействует многочисленные способы вербальной репрезентации высказываний-угроз. Прагматическая направленность консеквентных компонентов предвыборных высказываний-угроз в адрес многочисленных групп людей, отличающихся интересами, целями и по-разному представляющими себе будущее страны и главу государства, способствует внушительному охвату аудитории и увеличивает шанс того, что 
в фокусе воздействия программных материалов политика окажется избиратель, который проголосует за их автора.

Становится понятным, что, используя широкие возможности вербальной манифестации высказываний-угроз с негативными последствиями для не-избирателей, политик стремится противопоставить избирателя как представителя массового адресата всем тем третьим лицам и не-избирателям, которым он угрожает в предвыборной программе. Создается впечатление, что согласно высказываниям-угрозам, содержащимся в предвыборных программах кандидатов, избиратель - это тот, кто не нарушает законы, не поддерживает коррупцию, не распространяет фальшивую информацию, избиратель противопоставляется не-избирателям, оппонентам и тем, кто нарушает законы, ничего не делает для развития страны, предлагает реформы, которые не принесут пользы стране. Наличие указанного противопоставления служит причиной запуска механизма идентификации избирателем своего Я в предвыборном дискурсе, а также процесс причисления избирателем себя к определенной группе лиц и выбора соответствующей манеры поведения. В том случае, если направления оказываемого политиком менасивного воздействия совпадают с интересами и политическими предпочтениями избирателя и если избиратель не находит общих характеристик у себя и третьих лиц, то такой избиратель оказывается фокусным для политика и есть все основания полагать, что он проголосует за политика. Потому есть все основания утверждать, что именно на этом противопоставлении основано прагматическое использование политиками высказываний-угроз с различной адресатной направленностью консеквентного компонента.

Проведенный анализ позволил обнаружить определенные тенденции в использовании политиками высказываний со значением угрозы. В контексте российского предвыборного дискурса 2018 года прагматически эффективным инструментом является употребление кандидатом четырех разновидностей высказываний-угроз с различной адресатной направленностью консеквентного компонента. Также в российском предвыборном дискурсе 2018 года зафиксирована следующая тенденция в реализации конструкций со значением угрозы: чем меньше количество адресатных разновидностей высказыванийугроз содержит предвыборная программа политика, тем больше голосов он получит на выборах. Отмеченная тенденция может быть объяснена тем, что использование политиком незначительного количества разновидностей высказываний-угроз с различной адресатной направленностью консеквентного компонента позволяет ему фокусировать внимание на целевой аудитории, а также точнее формулировать основные идеи своей предвыборной программы и выбирать приоритетные направления прагма-эмоционального воздействия. Конечно, обращает на себя внимание тот факт, что Борис Титов и Сергей Бабурин выбиваются из обозначенной тенденции: Сергей Бабурин занял 8-е место на выборах и расположился на 4-м месте по количеству адресатных разновидностей менасивных высказываний, а Борис Титов использовал 
4 разновидности менасивов, однако ему удалось занять только 6-е место по итогам выборов 2018 года. Такая ситуация может быть объяснена тем, что для прагма-эмоционального воздействия предвыборных программ Бориса Титова и Сергея Бабурина оказался значимым ряд других прагматических параметров (характеристик) менасивных высказываний, требующих особого внимания с позиций деятельного подхода к общению.

Итак, рассмотрение высказываний со значением угрозы как регулятивных менасивных действий, реализованных в предвыборных программах кандидатов на пост Президента Российской Федерации, позволяет установить особенности их функционирования в формировании воздействующего потенциала программных материалов политиков. Зафиксированная тенденция не представляет собой строгую корреляционную зависимость между количеством адресатных разновидностей менасивов в предвыборной программе политика и количеством набранных им голосов на выборах, однако при планировании прагма-эмоционального воздействия менасивного дискурса на избирателей предпочтительно принимать во внимание полученные результаты. Выявленная тенденция и исключения из нее, скорее всего, свидетельствуют о необходимости учитывать при оценке прагма-эмоционального воздействия менасивов на избирателей и другие прагматические параметры, составляющие воздействующую характеристику таких высказываний, например, тематическую составляющую (тематику) консеквентного компонента, общее количество высказываний-угроз в предвыборной программе политика, а также ожидания избирателями угроз в программных материалах того или политического деятеля. Поэтому представляется перспективным продолжить функционально-семантический анализ предвыборных менасивов на основании перечисленных прагматических параметров, которые позволят определить интенсивность прагма-эмоционального воздействия высказыванийугроз того или иного политика на избирателей и выявить частотные разновидности менасивов, которые пригодны побуждать избирателей проголосовать за политика.

(C) А.А. Романов О.В. Новоселова 2020 (c)creative

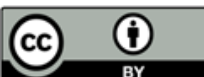

This work is licensed under a Creative Commons Attribution 4.0 International License https://creativecommons.org/licenses/by/4.0/

\section{СПИСОК ЛИТЕРАТУРЫ / REFERENCES}

Вежбицка А. Речевые акты // Новое в зарубежной лингвистике. 1985. Вып. 16. Лингвистическая прагматика. С. 251-275. [Vezhbitska, Anna. 1985. Speech Acts. Novoe v zarubezhnoi lingvistike 16. 251-275. (In Russ.)].

Гарпушкин В.Е. Прагматический аспект знаков и человеческое взаимопонимание // Философские науки. 1977. № 1. С.136-140. [Garpushkin, Vyacheslav E. 1977. The 
pragmatic aspect of signs and human understanding. Filosofskie nauki 1. 136-140. (In Russ.)].

Кастельс М. Власть коммуникации. Пер. с англ. М.: Изд. дом Высшей школы экономики, 2016. 564 c. [Kastel's, Manuel. 2016. Vlast' kommunikatsii (Power of communication). Moscow: Izd. dom Vysshei shkoly ekonomiki (In Russ.)].

Кацнельсон С.Д. Типология языка и речевое мышление. Л.: Наука. Ленингр. отд-ние, 1972. 216 c. [Katsnel'son, Solomon D. 1972. Tipologiya yazyka i rechevoe myshlenie (Typology of language and speech thinking). Leningrad: Nauka. Leningr. otd-nie (In Russ.)].

Лайнбарджер П. Психологическая война. Теория и практика обработки массового сознания. М.: Центроплиграф, 2013. 445 с. [Lainbardzher, Pol. 2013. Psikhologicheskaya voina. Teoriya i praktika obrabotki massovogo soznaniya (Psychological warfare. Theory and practice of mass consciousness processing). Moscow: Tsentropligraf (In Russ.)].

Леонтьев А.А. Высказывание как предмет лингвистики, психолингвистики и теории коммуникации // Синтаксис текста. М.: Наука, 1979. С. 18-36. [Leont'ev, Aleksey A. 1979. Vyskazyvanie kak predmet lingvistiki, psikholingvistiki i teorii kommunikatsii (Statement as a subject of linguistics, psycholinguistics and communication theory), 18-36. Moscow: Nauka (In Russ.)].

Леонтьев А.Н. Общее понятие деятельности // Хрестоматия по психологии. М.: Просвещение, 1977. C. 206-214. [Leont'ev, Aleksey N. 1977. Obshchee ponyatie deyatel'nosti (General concept of activity), 206-214. Moscow: Prosveshchenie (In Russ.)].

Най Дж.С. Гибкая власть. Как добиться успеха в мировой политике. Пер. с англ. М.: ФСПИ Тренды, 2006. 221 с. [Nye, Joseph Samuel. 2006. Gibkaya vlast'. Kak dobit'sya uspekha v mirovoi politike (Soft Power: The Means to Success in World Politics). Moscow: FSPI Trendy (In Russ.)].

Новоселова О.В. Коммуникативная толерантность vs коммуникативная справедливость высказываний различной прагматической направленности [Электронный ресурс] // Мир лингвистики и коммуникации: электронный научный журнал. 2017. № 2. C. 125-147. URL: http://tverlingua.ru (дата обращения: 15.01.2020). [Novoselova, Olga V. 2017. Communicative tolerance vs communicative fairness of different pragmatic orientation statements. World of linguistics and communication: electronic scientific journal 1. 125-147. (In Russ.)].

Новоселова О.В. Менасивные высказывания в коммуникативно справедливом пространстве диалога // Русский язык и литература в мультикультурном пространстве: материалы Всероссийской научно-практической конференции. Ч. 2. Комсомольск-наАмуре: АмГПГУ, 2017а. С. 67-73. [Novoselova, Olga V. 2017a. Menasivnye vyskazyvaniya $\mathrm{v}$ kommunikativno spravedlivom prostranstve dialoga (Menasive statements in communicative fair space of dialogue). Materialy Vserossiiskoi nauchnoprakticheskoi konferentsii, 67-73. Komsomolsk-on-Amur: AmGPGU (In Russ.)].

Новоселова О.В. Средства языковой репрезентации менасивов в программном дискурсе кандидатов на пост Президента РФ в 2018 году // Инновационные подходы к развитию науки и производства регионов: сборник научных трудов по материалам Национальной научно-практической конференции. Тверь: ТГСХА, 2019. С. 391-394. [Novoselova, Olga V. 2019. Sredstva yazykovoi reprezentatsii menasivov v programmnom diskurse kandidatov na post Prezidenta RF v 2018 godu (Means of language representation of menasives in the program discourse of presidential candidates in the Russian Federation in 2018). Sbornik nauchnykh trudov po materialam Natsional'noi nauchno-prakticheskoi konferentsii, 391-394. Tver: TGSKhA, (In Russ.)].

Романов А.А. Системный анализ регулятивных средств диалогического общения. М.: Институт языкознания АН ССCР, 1988. 183 с. [Romanov, Aleksey A. 1988. Sistemnyi 
analiz regulyativnykh sredstv dialogicheskogo obshcheniya (System analysis of regulatory means of dialogic communication). Moscow: Institut yazykoznaniya AN SSSR (In Russ.)].

Романов А.А. Политическая лингвистика: Функциональный подход. Москва-Тверь: Институт языкознания РАH, 2002. 191 c. [Romanov, Aleksey A. 2002. Politicheskaya lingvistika: Funktsional'nyi podkhod (Political Linguistics: A Functional Approach). Moscow-Tver: Institut yazykoznaniya RAN (In Russ.)].

Романов А.А. Лингвопрагматическая модель речевого управления диалогом: системный анализ с примерами из русского и немецкого языков. М.: URSS (ЛЕНАНД), 2020. 264 c. [Romanov, Aleksey A. 2020. Lingvopragmaticheskaya model' rechevogo upravleniya dialogom: sistemnyi analiz s primerami iz russkogo i nemetskogo yazykov (Linguopragmatic model of speech dialogue: system analysis with examples from Russian and German). Moscow: URSS (In Russ.)].

Романов А.А., Новоселова О.В. Дискурс угрозы в социальной интеракции (функционально-семантический анализ). Москва-Тверь: Институт языкознания РАН, Тверская ГСХА, 2013. 168 с. [Romanov, Aleksey A. \& Olga V. Novoselova. 2013. Diskurs ugrozy $v$ sotsial'noi interaktsii (funktsional'no-semanticheskii analiz) (Threat discourse in social interaction (functional-semantic analysis)). Moscow-Tver: Institut yazykoznaniya RAN, Tverskaya GSKhA (In Russ.)].

Романов А.А., Новоселова О.В. Топономия психологического пространства вербальных практик-угроз // Вестник Тверского Государственного Университета. Серия: Педагогика и психология. 2013a. № 2. С. 20-32. [Romanov, Aleksey A. \& Olga V. Novoselova. 2013a. Toponomy of the psychological space of verbal threat practices. Vestnik Tverskogo Gosudarstvennogo Universiteta. Seriya: Pedagogika i psikhologiya 2. 20-32. (In Russ.)].

Романов А.А. Новоселова О.В. Предвыборные менасивы как особый прагматический тип высказываний со значением угрозы // Вестн. Сев. (Арктич.) федер. ун-та. Сер.: Гуманит. и соц. науки. 2020. № 1. C. 44-52. DOI: 10.17238/issn2227-6564.2020.1.44. [Romanov, Aleksey A. \& Olga V. Novoselova. 2020. Predvybornye menasivy kak osobyi pragmaticheskii tip vyskazyvanii so znacheniem ugrozy (Pre-Election Threats as a Special Pragmatic Type of Statements). Vestnik Severnogo (Arkticheskogo) federal'nogo universiteta. Ser.: Gumanitarnye i sotsial'nye nauki 1.44-52. DOI: 10.17238/issn22276564.2020.1.44. (In Russ.)].

Романов А.А., Ульянич Г.А. Мелолийный дискурс как информационный медиум в системе публичных коммуникаций. Москва-Тверь: ИЯ РАН; ТИПЛ и МК, Тверская ГCXA, 2014. 163 c. [Romanov, Aleksey A. \& Gennadiy A. Ul'yanich. 2014. Meloliinyi diskurs kak informatsionnyi medium $v$ sisteme publichnykh kommunikatsii (Meloline discourse as an information medium in the system of public communications.). MoscowTver: Institut yazykoznaniya RAN, Tverskaya GSKhA (In Russ.)].

Романов А.А., Романова Е.Г., Воеводкин Н.Ю. Имя собственное в политике. М.: Лилия ЛТД, 2000. 112 с. [Romanov, Aleksey A., Elena G. Romanova \& Nikolay Yu. Voevodkin. 2000. Imya sobstvennoe v politike (The proper name in politics). Moscow: Liliya LTD (In Russ.)].

Black, Peter. 1993. Soft Kill: Fighting Infrastructure Wars in the 21st Century. Wired, JulyAugust. 49-50.

Khanna, Parag. 2016. Connectography. Mapping the future of global civilization. New York: Penguin Random House LLC.

Leonard, Mark. 2016. Introduction: connectivity wars. In Mark Leonard (eds.), Connectivity wars. Why migration, finance and trade are the geo-economic battlegrounds of the future. 13-27. London: European Council on Foreign Relations. 
Mattern, Janice Bially. 2005. Why Soft Power Is Not So Soft: Representational Force and the Sociolinguistic Construction of attraction in World Politics. Millennium: Journal of International Studies 33 (3). 583-612.

Rehbein, Jochen. 1977. Komplexes Handeln: Elemente zur Handlungstheorie der Sprache. Stuttgart: Metzler.

Schlenker, Barry R. 2003. Self-presentation. In Mark R. Leary (eds.), Handbook of Self and Identity. $488-518$.

Schlenker, Barry R. \& Michael F. Weigold. 1990. Self-consciousness and self-presentation: Being autonomous versus appearing autonomous. Journal of Personality and Social Psychology 59, 820-828.

Vosoughi, Soroush, Deb Roy \& Sinan Aral. 2018. The Spread of True and False News Online. Science 359 (6380). 1146-1151.

\section{СПИСОК ИСТОЧНИКОВ ПРИМЕРОВ}

Основное содержание послания Президента РФ Владимира Путина Федеральному Собранию [Электронный ресурс] // Российская газета, 2018. URL: https: rg.ru.poslanie.pdf (дата обращения: 10.03.18).

Предвыборная программа Всероссийской политической партии «Партия роста» на выборах Президента Российской Федерации [Электронный ресурс]. URL: http://vibory-rf.ru/kandidaty-2018/boris-titov (дата обращения: 10.03.18).

Мощный рывок вперед! Программа В.В. Жириновского «100 пунктов» [Электронный pecypc]. URL: https://ldpr.ru/leader/Powerful_leap_forward_2018, (дата обращения: 10.03.18).

Дорога в будущее. Основные направления президентской программы Григория Алексеевича Явлинского [Электронный ресурс]. URL: https://2018.yavlinsky.ru/programm (дата обращения: 10.03.18).

Предвыборная программа кандидата Бабурина Сергея [Электронный ресурс]. URL: http://baburin2018.ru/programma (дата обращения: 10.03.18).

Платформа Ксении Собчак. 123 Трудных шага [Электронный ресурс]. URL: https://sobchakprotivvseh.ru/steps123 (дата обращения: 10.03.18).

Программа товарища Максима Сурайкина [Электронный ресурс]. URL: http://komros.info/programma-tovarischa-maksima-suraykina (дата обращения: 10.03.18).

20 шагов Павла Грудинина. Кандидат в президенты России обращается к каждому [Электронный ресурс]. URL: http://grudininkprf.ru/programma (дата обращения: 10.03.18).

Результаты выборов президента России 2018 [Электронный ресурс]. URL: http://vibory-rf.ru/rezultaty-vyborov-prezidenta-rossii-2018 (дата обращения: 1.05.18).

\section{Article history:}

Received: 17 January 2020

Revised: 10 March 2020

Accepted: 14 March 2020

\section{История статьи:}

Дата поступления в редакцию: 17 января 2020

Дата принятия к печати: 14 марта 2020 
Сведения об авторах:

РОМАНОВ АЛЕКСЕЙ АРКАДЬЕВИЧ - доктор филологических наук, профессор, заслуженный деятель науки РФ, почетный работник высшего профессионального образования РФ, заведующий кафедрой теории языка и межкультурной коммуникации Тверской государственной сельскохозяйственной академии, директор Института прикладной лингвистики и массовых коммуникаций ТГСХА, профессор кафедры фундаментальной и прикладной лингвистики Тверского государственного университета, главный редактор электронного научного журнала Мир лингвистики и коммуникации (http://www.tverlingua.ru). Основатель Тверской научной школы «Динамическая модель регулятивной коммуникации» (семантика и прагматика общения). Опубликовал более 547 работ, среди которых 30 монографий. Сфера научHblx интересов: теоретическая, прикладная и когнитивная лингвистика, психолингвистика, теория коммуникации.

\section{Контактная информация:}

Тверская государственная сельскохозяйственная академия 170904, Россия, г. Тверь, ул. Маршала Василевского (Сахарово), д. 7

Тверской государственный университет

170100, Россия, г. Тверь, ул. Желябова, 33

e-mail: romanov_tgsha@mail.ru

НОВОСЕЛОВА ОЛЬГА ВЛАДИМИРОВНА - кандидат филологических наук, доцент, доцент кафедры теории языка и межкультурной коммуникации Тверской государственной сельскохозяйственной академии. Сфера научных интересов: политическая коммуникация, предвыборный дискурс, прагматика, прикладная и когнитивная лингвистика, коммуникативный конструктивизм. Является автором более 150 научных трудов, среди которых монография Дискурс угрозы в сочиальной интеракции (2013), а также автором и соавтором более 40 учебных пособий.

\section{Контактная информация:}

Тверская государственная сельскохозяйственная академия 170904, Россия, г. Тверь, ул. Маршала Василевского (Сахарово), д. 7 e-mail: olvnov@mail.ru

\section{Bionotes:}

ALEKSEY ROMANOV is a full professor, Doctor of Philology, Honored Scholar of the Russian Federation, Honorary Worker of Higher Professional Education of the Russian Federation, Head of the Department of Theory of Language and Intercultural Communication and Director of the Institute of Applied Linguistics and Mass Communications at Tver State Agricultural Academy, Professor at Tver State University, Editor-in-Chief of the electronic scholarly journal World of Linguistics and Communication. He is the founder of the research school of Dynamic model of regulatory communication. He has published 547 research papers. His research interests embrace theoretical, applied and cognitive linguistics.

\section{Contact information:}

Tver State Agricultural Academy

7 Vasilevsky Street, Sakharovo, Tver, 170904, Russia

Tver State University

33 Zhelyabova Street, Tver, 170100, Russia

e-mail: romanov_tgsha@mail.ru 
OLGA NOVOSELOVA is Doctor of Philology, Associate Professor at the Department of Theory of Language and Intercultural Communication at Tver State Agricultural Academy. Her research interests include political communication, pre-election discourse, pragmatics, applied and cognitive linguistics, communicative constructivism. She is the author of more than 150 scientific papers, including the monograph Diskurs ugrozy v sotsial'noi interaktsii [Discourse of Threat in Social Interaction], Moscow-Tver, 2013, as well as the author and co-author of more than 40 course books.

\section{Contact information:}

Tver State Agricultural Academy

7 Vasilevsky Street, Sakharovo, Tver, 170904, Russia

e-mail:olvnov@mail.ru 